\title{
Antigenic GM3 Lactone Mimetic Molecule Integrated Mannosylated Glycopeptide Nanofibers for the Activation and Maturation of Dendritic Cells
}

\author{
Gokhan Gunay, ${ }^{\dagger, \ddagger}, \|$ Melis Sardan Ekiz, ${ }^{\dagger, \ddagger}$ Xhenti Ferhati, ${ }^{\S}$ Barbara Richichi, ${ }^{\S}$ Cristina Nativi, ${ }^{*},{ }_{(0)}$

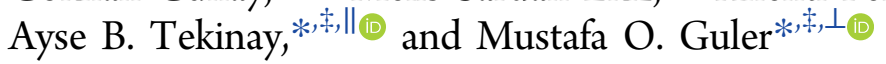 \\ ${ }^{\ddagger}$ Institute of Materials Science and Nanotechnology, National Nanotechnology Research Center (UNAM), Bilkent University, \\ Ankara 06800, Turkey \\ "Neuroscience Graduate Program, Bilkent University, Ankara 06800, Turkey \\ ${ }^{\S}$ Department of Chemistry "Ugo Schiff”, University of Florence, Sesto Fiorentino, Florence 50019, Italy \\ ${ }^{\perp}$ Institute for Molecular Engineering, University of Chicago, Chicago, Illinois 60637, United States
}

Supporting Information
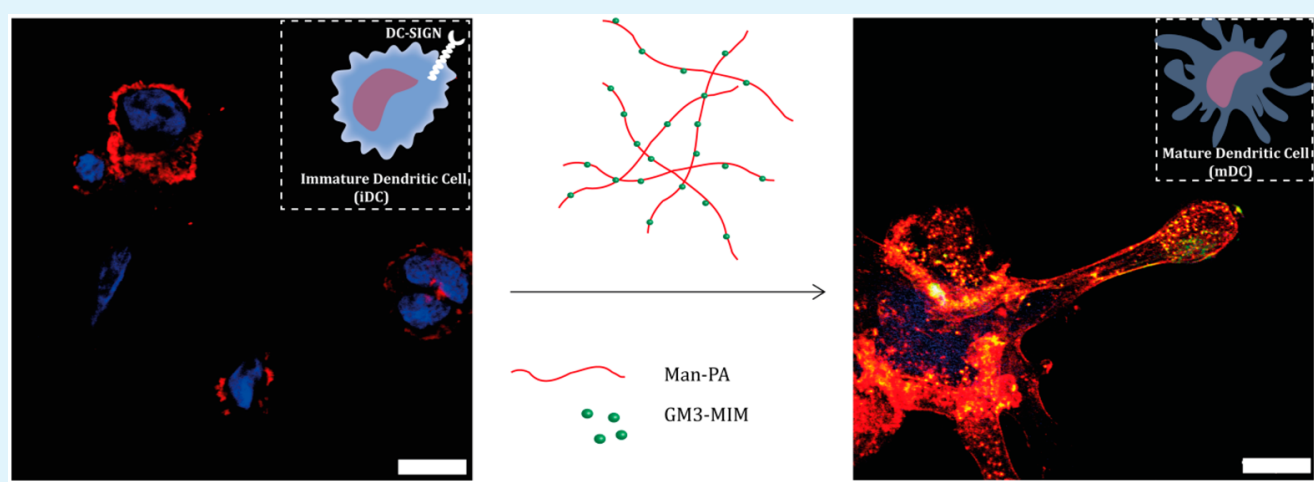

ABSTRACT: The ability of dendritic cells to coordinate innate and adaptive immune responses makes them essential targets for vaccination strategies. Presentation of specific antigens by dendritic cells is required for the activation of the immune system against many pathogens and tumors, and nanoscale materials can be functionalized for active targeting of dendritic cells. In this work, we integrated an immunogenic, carbohydrate melanoma-associated antigen-mimetic GM3-lactone molecule into mannosylated peptide amphiphile nanofibers to target dendritic cells through DC-SIGN receptor. Based on morphological and functional analyses, when dendritic cells were treated with peptide nanofiber carriers, they showed significant increase in antigen internalization and a corresponding increase in the surface expression of the activation and maturation markers CD86, CD83 and HLA-DR, in addition to exhibiting a general morphology consistent with dendritic cell maturation. These results indicate that mannosylated peptide amphiphile nanofiber carriers are promising candidates to target dendritic cells for antigen delivery.

KEYWORDS: cancer immunotherapy, cancer antigens, dendritic cells, carbohydrate melanoma associated antigen, peptide amphiphiles

\section{INTRODUCTION}

The immune system is a complex machinery that requires regulatory interplay between its innate and adaptive compartments to ensure an efficient surveillance against pathogens and cancer cells. Generally, the immune system is not efficiently induced against tumors, and cancer cells are tolerated because of the evasion mechanisms they employ. ${ }^{1}$ Because cancer cells are poor antigen-presenting cells (APC), a robust antitumor immune response cannot be elicited. Cancer immunotherapy approaches aim to induce a long-lasting and robust immunity, enabling cancer patients to fight against their own cancer. Thus, understanding of cancer and immune system cross-interactions holds a paramount importance for the improvement and development of new cancer immunotherapy strategies. ${ }^{2,3}$
Dendritic cells (DCs) ${ }^{4}$ are promising candidates for cancer immunotherapy, as they capture, process and present antigens to $\mathrm{T}$-cells for the initiation of adaptive immunity. ${ }^{5,6} \mathrm{~T}$-cells presented and activated with a tumor antigen initiate anticancer responses. The activation of dendritic cells and their capability to activate $\mathrm{T}$ cells depend on their maturation state, ${ }^{7}$ which is determined by the upregulation of costimulatory molecules as well as by morphological changes such as increased cell surface area, which enables more connections with surrounding cells. ${ }^{8}$ Several attempts have been made to pulse DCs with specific

\footnotetext{
Received: March 22, 2017

Accepted: April 26, 2017

Published: April 26, 2017
} 


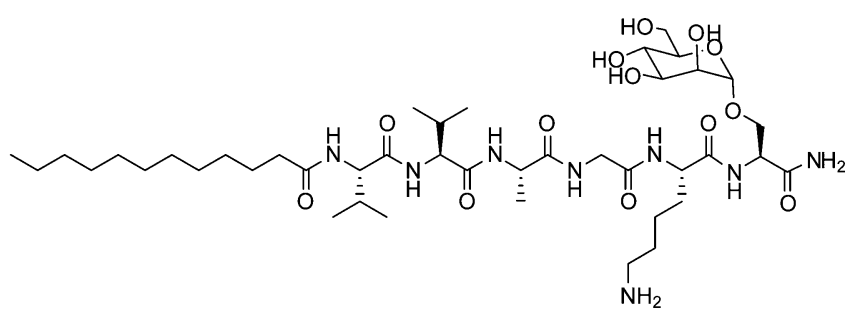

Man-PA

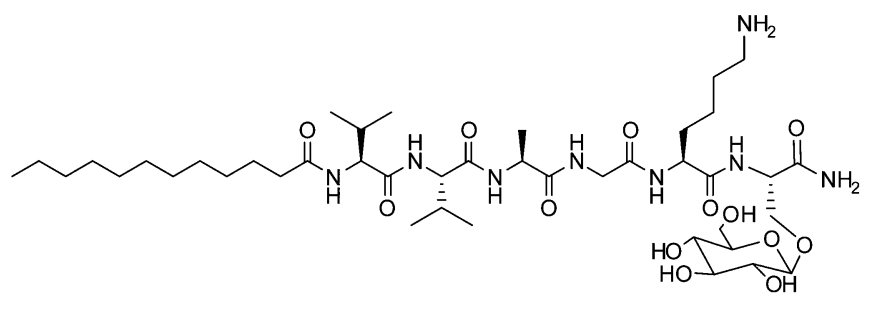

Glc-PA

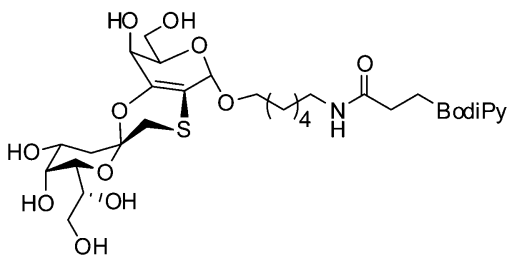

fluorescent GM3-MIM

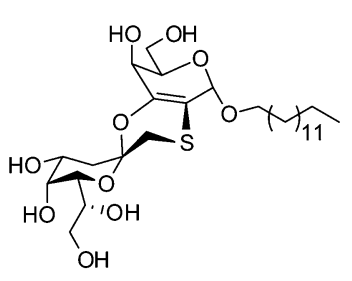

alkyl derivative of GM3-MIM

Figure 1. Chemical structures of the self-assembling molecules.

antigens for the induction of anticancer immunity. The targeting of C-type lectin receptors (CLR) is critical for the pulsing and maturation of DCs. ${ }^{9,10}$ Among CLRs, dendritic cell specific intracellular adhesion molecule-3-grabbing nonintegrin (DC-SIGN) is a receptor that is mainly expressed on immature dendritic cells (iDCs), ${ }^{11}$ and modulates the uptake of specific pathogens through its interactions with mannosylated structures. $^{12-14}$ Indeed, several studies reported that DC-SIGN receptors can be targeted by using mannosylated structures. ${ }^{15-17}$

Discovery of human cancer antigens enabled scientists to develop new immunotherapy strategies. ${ }^{18,19}$ Melanoma is often an intractable cancer type and has been reported to be a promising target for immunotherapy. ${ }^{20}$ GM3 ganglioside is a widespread glycosphingolipid overexpressed in metastatic melanoma cells, and several studies investigated its potential as a melanoma associated antigen. ${ }^{21}$ A metabolite of GM3 ganglioside, GM3 lactone, is also present in melanoma cells. Even though it is more immunogenic than GM3 ganglioside, its amount is generally not sufficient to cause an efficient immune response because of its instability in acidic tumor environment. Previously, it was shown that a permannosylated dendron-containing hydrolytically stable mimetic of GM3 lactone (antigenic GM3 lactone mimetic) is able to induce DC activation through DC-SIGN receptor. ${ }^{15}$

Recently, antigens delivered through nanoscale materials have been shown to provide considerable advantages over soluble antigen administration, due to the stimulation of antigen uptake and cellular activation by surface-functionalized delivery vectors. Gold and PLGA nanoparticles, dendrimers and liposomes have previously been functionalized for in vitro dendritic cell targeting purposes. ${ }^{15,22,23}$ Molecular self-assembly is a process by which molecules are organized into complex structures through noncovalent interactions. Functional self-assembled nanomaterials can be designed through a bottom-up fabrication technique, ${ }^{24,25}$ which can be used in many biomedical applications such as drug delivery and regenerative medicine. ${ }^{26,27}$ Among these materials, self-assembling peptide amphiphiles (PA) have been extensively used for their biocompatibility and biodegradability. ${ }^{28}$ In addition, these molecules can be designed to form nanofibers and can be tailored with a variety of functional groups and residues for cellular targeting. ${ }^{29,30}$

Here self-assembled mannosylated glycopeptide nanofibers were used for the delivery of an immunogenic mimetic of the GM3 lactone antigen. Sugar specificity was investigated between mannose and glucose in terms of DC-SIGN receptor targeting and antigen delivery into immature DCs. We showed the activation and maturation of DCs in terms of phenotypic expression of surface costimulatory molecules and morphological changes upon DC-SIGN targeting.

\section{RESULTS AND DISCUSSION}

Preparation of Fluorescent GM3-MIM Integrated Glycopeptide Nanofibers. A glycosylated amino acid residue was first synthesized in four steps prior to the synthesis of glycopeptide PA molecules (Scheme S1). All compounds synthesized in each step and the final molecule, Fmoc-L-Ser $[\alpha-$ $\left.\mathrm{D}-\mathrm{Man}(\mathrm{OAc})_{4}\right]-\mathrm{OH}$, were characterized by NMR and mass spectrometry (Figures S1-S8). Synthesized Fmoc-L-Ser $[\alpha-\mathrm{D}$ $\left.\mathrm{Man}(\mathrm{OAc})_{4}\right]-\mathrm{OH}$ was used as the first amino acid residue of the glycopeptide sequence during the elongation of the peptide on solid support. After the resin cleavage, the amphiphilic glycopeptide was obtained in protected form due to the acetylated sugar hydroxyl groups, and deprotection reaction was carried out in solution phase to prevent O-glycosidic bond cleavage during acid treatment in solid phase peptide synthesis. ${ }^{31}$ Although the mannosylated amino acid residue existed at the C-terminus of the peptide segment, amphiphilic character was obtained by the conjugation of a hydrocarbon tail to the N-terminus of the peptide moiety (Figure 1). Here the mannose residue was chosen because of its high affinity to DC-SIGN receptor, enabling the induction of DC activation. In addition, an additional glycopeptide molecule, Glc-PA, was synthesized by using a glucosylated serine amino acid in the sequence to test the sugar specificity of the glycosylated PA. The chemical structures of the two amphiphilic glycopeptide molecules, Man-PA and Glc-PA, were verified by liquid chromatography and mass spectrometry (Figure S9).

Before the integration of fluorescent GM3-MIM into the glycopeptide systems, the amphiphilic glycopeptides were individually investigated in terms of their secondary structure and morphological properties at physiological $\mathrm{pH}$. Diluted solutions of Man-PA and Glc-PA were studied by circular dichroism (CD) spectroscopy and the results revealed that both pure systems were oriented in a $\beta$-sheet conformation, exhibiting a positive peak at $202 \mathrm{~nm}$ and negative peak at 
$218 \mathrm{~nm}$ (Figure S13). Morphological observations were also carried out under scanning transmission electron microscopy (STEM) and both glycopeptide samples, regardless of the type of sugar they contain, were found to form high-aspect-ratio nanofibers with diameters on the order of 9-11 nm and lengths reaching several micrometers (Figures S14A, B).

Because of its poor solubility in water, the integration of GM3-MIM into the glycopeptide nanofibers was achieved by solvent exchange (Figure 2). Although amphiphilic glycopeptide
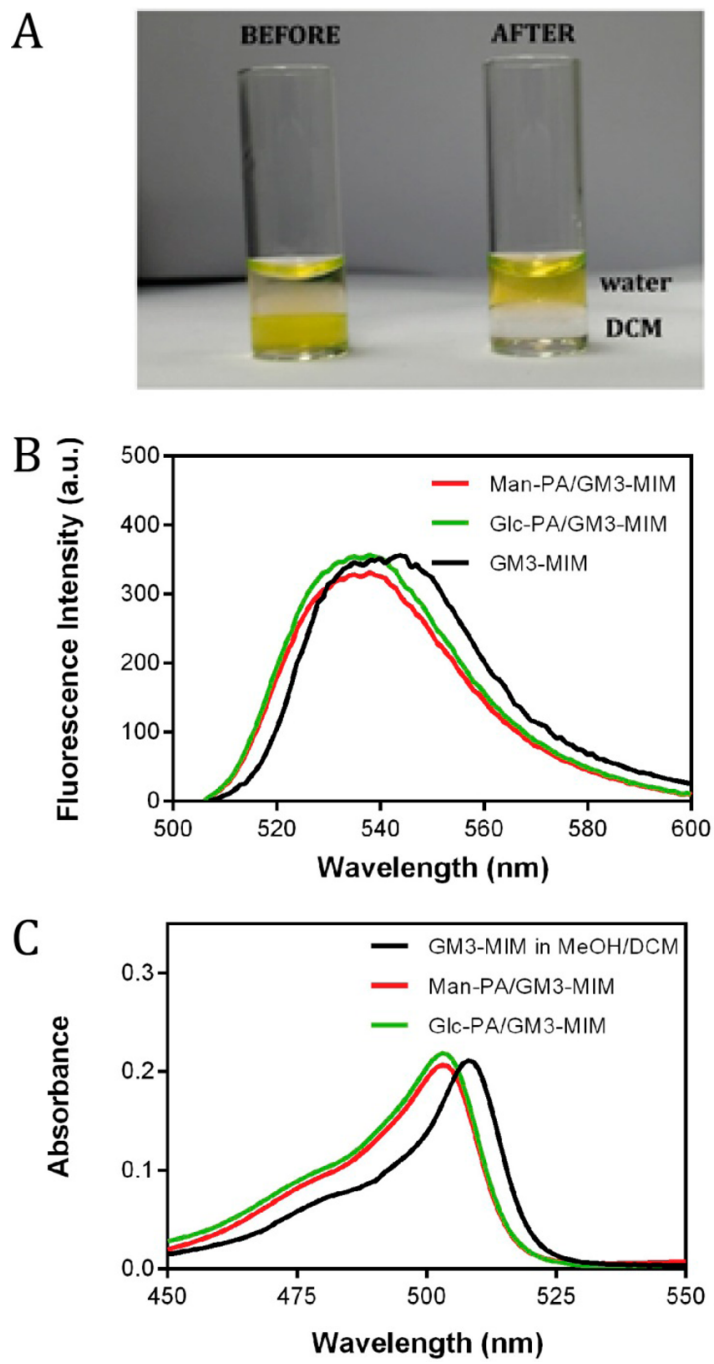

Figure 2. (A) Image of solvent exchange (DCM: $\mathrm{H}_{2} \mathrm{O}$ ) for GM3-MIM molecule. (B) Fluorescence and (C) UV spectra of GM3-MIM and GM3-MIM integrated glycopeptide solutions dissolved in $\mathrm{DCM}: \mathrm{MeOH}(7: 1)$ and water, respectively.

solutions were dissolved in slightly acidic water, GM3-MIM was solubilized in a DCM:MeOH (7:1, v/v \%) mixture. Prior to the addition of the GM3-MIM solution, glycopeptide solutions were separately sonicated at $50{ }^{\circ} \mathrm{C}$ at $\mathrm{pH} 6$ to disrupt self-assembly and generate single glycopeptide molecules. The glycopeptides carry a positive net charge from their lysine residue, which increases their water solubility and facilitates their integration during self-assembly, as electrostatic interactions force the hydrophobic tail of glyco-PAs within the nanofiber structure, whereas lysine and serine-conjugated glucose/mannose residues are presented at the nanofiber periphery. After addition of the antigen solution, heating and sonication processes allow the hydrophobic tail region of GM3-MIM to interact with the hydrocarbon chain segment and hydrophobic amino acids of glycopeptides, which facilitates the transfer of GM3-MIM into the aqueous environment. In addition, as GM3-MIM exhibits a similar amphiphilic structure, it is likely that the molecule also participates in nanofiber assembly with its hydrophobic tail facing to the nanofiber core and hydrophilic ring structure facing to the hydrophobic environment.

Photographs taken before and after solvent exchange confirmed the transfer of GM3-MIM molecule, as BODIPYtagged GM3-MIM could no longer be observed in the DCM phase following the exchange (Figure 2A). Spectroscopic analyses were also conducted to verify the transfer of GM3-MIM molecule into the water phase. The fluorescence and UV spectra of fluorescent GM3-MIM integrated glycopeptide systems were blue-shifted relative to GM3-MIM alone, which was also in good agreement with visual observations (Figures 2B, C). UV spectra results also showed that GM3-MIM exhibited comparable absorbance values before and after its integration into glycoPAs, suggesting that it was successfully integrated into the PA system and that integration was quantitative.

The successful transfer of GM3-MIM into the glycopeptide solutions was followed by the investigation of the secondary structure and morphology of glycopeptides in the presence of the antigen by using CD and STEM, respectively. CD results indicated that GM3-MIM integrated glycopeptide solutions showed a $\beta$-sheet composition (Figure S13). Although a higher degree of bundling was observed after the integration in STEM images, the PAs nevertheless self-assembled into nanofibers without any significant change in their diameters, indicating the preservation of the PA packing process (Figures 3A, B). Moreover, because of the sulfur content of GM3-MIM molecule, it was possible to test whether the antigen was successfully integrated into the glycopeptide nanofibers. Sulfur and oxygen mapping was performed under TEM to confirm that GM3-MIM molecules were present in glycopeptide nanofibers (Figure S15). In addition, zeta potential measurements were performed in order to investigate the surface charge of the glyco-PAs, which was found to be around $+27 \mathrm{mV}$ (Figure S16).

Cell Viability Assay and iDC Differentiation from THP-1 Monocytes. Cytotoxicity is another key factor when designing materials for targeting purposes, and according to live-dead assay, $150 \mu \mathrm{M}$ of glycopeptide nanofibers were found to be nontoxic to cells (Figure S17). Immature dendritic cells were obtained from THP-1 human monocytes as previously reported. ${ }^{32}$ Cells differentiation was monitored by quantifying the surface expression of CD86, and flow cytometry analyses were performed to confirm the de novo expression of this marker (Figure S18A). In addition, the cells displayed extrusions and protrusions that are consistent with the typical morphology of immature dendritic cells (Figure S18B). As glyco-PAs are biocompatible at $150 \mu \mathrm{M}$, and they formed nanofibers at this concentration (as confirmed by TEM and CD), subsequent in vitro experiments were performed using this concentration.

Internalization of Fluorescent GM3-MIM Integrated Glycopeptide Nanofibers. Previous studies have reported the internalization of mannosylated structures through DC-SIGN receptors. Considering that iDCs strongly express DC-SIGN on their surfaces, ${ }^{11}$ we investigated the internalization of GM3-MIM integrated glycopeptide nanofibers through confocal microscopy imaging after obtaining iDCs from THP-1 monocytes. The charge of a material has a critical influence over internalization, and it is feasible that different 


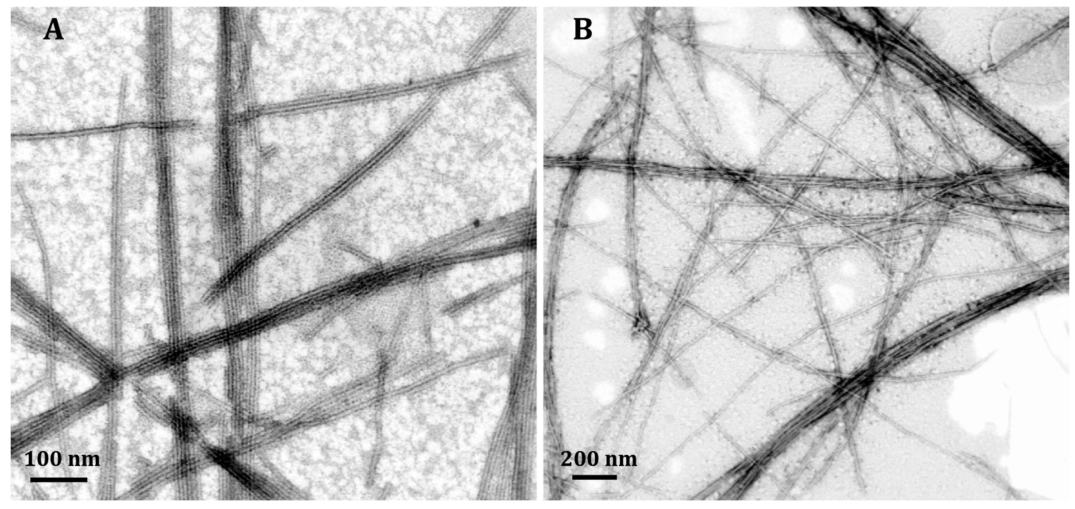

Figure 3. STEM images of (A) Man-PA/GM3-MIM and (B) Glc-PA/GM3-MIM.
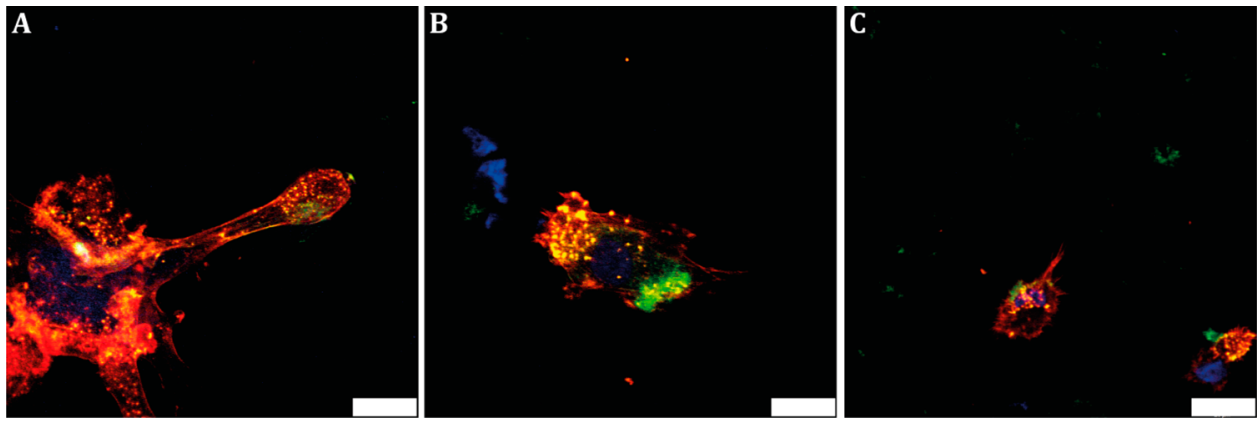

Figure 4. Uptake of BODIPY conjugated GM3-MIM and morphological changes of iDCs when treated with (A) Man-PA/GM3-MIM, (B) Glc-PA/GM3-MIM, and (C) only GM3-MIM for $24 \mathrm{~h}$. Nuclei were stained with To-Pro (blue), cytoskeletons were stained with Phalloidin (red) and BODIPY green (GM3-MIM). Scale bars: $20 \mu \mathrm{m}$.

surface charges could alter the uptake of otherwise similar PA structure. ${ }^{33}$ However, Zeta potential results indicated that Man-PA and Glc-PA had similar charges at around $+27 \mathrm{mV}$ (Figure S16), suggesting that any possible difference in the uptake would not be caused by surface charge.

Cells were treated with Man-PA/GM3-MIM, Glc-PA/ GM3-MIM or control GM3-MIM for $24 \mathrm{~h}$. BODIPY-conjugated GM3-MIM was used for internalization analyses, and cells were also stained with phalloidin and To-Pro for cytoskeletal and nuclear staining, respectively. Confocal imaging indicated that, under Man-PA/GM3-MIM treatment, antigen uptake was higher compared to other groups (Figure 4A). This uptake can be attributed to the high affinity of mannose to DC-SIGN, and induced maturation as observed by changes in cell morphology. However, Glc-PA/GM3-MIM was internalized only to a lesser extent, and could not promote an $\mathrm{mDC}$-like morphology as well as Man-PA/GM3-MIM (Figure 4B). However, the uptake of Glc-PA/GM3-MIM was nevertheless higher compared to the control, GM3-MIM (Figure 4C). Complementary results were also obtained quantitatively through flow cytometry analyses. Man-PA/GM3-MIM showed 1.5-fold higher uptake compared to Glc-PA/GM3-MIM and almost 7-fold higher uptake compared to GM3-MIM (Figure S19). Glc-PA/GM3-MIM showed 6-fold higher uptake compared to GM3-MIM (Figure S19). This can be explained by the positive charge of Man-PA and Glc-PA (GM3-MIM has no charge) and by the ability of nanofiber structure to promote endocytosis.

Surface Marker Analyses of Dendritic Cell Activation. Activation and maturation state of DCs were measured by analyzing the expression of CD86, CD83 and MHC-II receptors. Increased expression of these molecules was previously shown to be associated with the maturation and activation status of dendritic cells. ${ }^{15,34}$ CD86 is a costimulatory molecule interacting with CD28 on $\mathrm{T}$ cells and is required for proper activation. ${ }^{35}$ Man-PA/GM3-MIM group significantly increased the expression of CD86 compared to other groups as measured by flow cytometry (Figure 5A). CD83 is another activation marker for DCs and its expression is up-regulated during the transition from immature state to mature state. ${ }^{36,37}$ Man-PA/GM3-MIM also significantly increased the expression of CD83 compared to the other compounds (Figure 5B), and the same pattern was observed for the expression of MHC-II (Figure 5C), which is a molecule essential for the proper presentation of antigens. ${ }^{38}$ Expression profiles obtained by flow cytometry analysis were compatible with fluorescent imaging (Figure 4) and flow cytometry analyses (Figure S19) of GM3-MIM internalization. In summary, considering the necessity of the up-regulation of these molecules for DC activation and maturation, Man-PA/ GM3-MIM was shown to have a significant role in inducing the activation and maturation of DCs in terms of surface expression of CD86, CD83, and MHC-II.

Morphological Analyses of Dendritic Cell Activation. Morphological analyses were carried out using scanning electron microscopy (SEM) to investigate the changes in surface area and cellular size. In agreement with fluorescent imaging data (Figure 4), iDCs treated with Man-PA/GM3-MIM increased their surface area and morphologically became more $\mathrm{mDC}$-like (Figure 6A) compared to Glc-PA/GM3-MIM (Figure 6B) and GM3-MIM (Figure 6C). It should be noted that increases in surface area facilitate the interaction of DCs with surrounding cells, and are therefore important for antigen presentation. Man-PA and Glc-PA nanofibers lacking GM3-MIM integration were also tested for morphological analyses to ensure that the changes were due to GM3-MIM delivery. According to SEM images, 

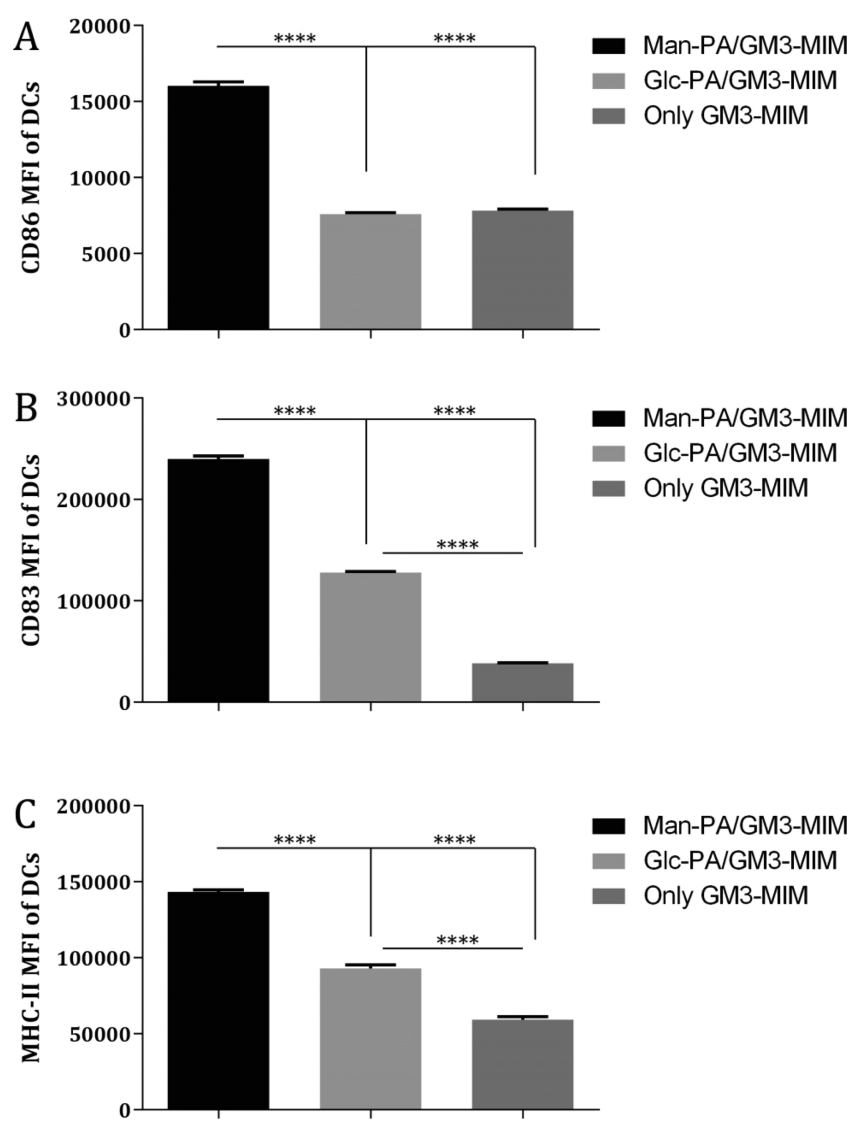

Figure 5. Surface expression MFI values of (A) CD86, (B) CD83, and (C) MHC-II under Man-PA/GM3-MIM, Glc-PA/GM3-MIM, and only GM3-MIM treatment for $24 \mathrm{~h}$. Values represent mean \pm SEM $(* * * * p<0.0001)$.

Man-PA (Figure S20A) and Glc-PA (Figure S20B) did not have any effect on morphological changes in $\mathrm{iDCs}$, indicating the dominant effect of the antigen delivery through Man-PA/GM3-MIM.

\section{CONCLUSION}

In this study, peptide amphiphile molecules presenting mannose moieties were used for the targeting of the DC-SIGN receptor and the delivery of an immunogenic mimetic of GM3-lactone antigen to induce DC maturation and activation. GM3-MIM presented on Man-PA nanofibers were more efficient over Glc-PA/GM3-MIM and GM3-MIM in terms of antigen internalization, stimulation of CD86, CD83, and MHC-II expression and the induction of a mature DC-like morphology, suggesting that mannose/DC-SIGN interactions are primarily responsible for uptake. Considering the instability of GM3 lactone molecule and its low concentration under physiological conditions, Man-PA is a promising delivery vehicle for the internalization of this immunogenic antigen through DC-SIGN receptors. We show that the targeted delivery of antigens by using Man-PA to activate iDCs can play important roles in inducing cellular immunity against cancer conditions, and that correctly delivered GM3-MIM can be suitably presented to the immune system. Peptide amphiphiles are biocompatible and biodegradable materials with a broad range of potential applications for tissuespecific targeting and delivery. Unlike conventional delivery vesicles, such as liposomes, PA systems can be functionalized with targeting molecules and can naturally localize to tissues of interest because of the bioactive epitopes expressed on their surfaces. These epitope sequences can also be designed to interact with specific cell surface receptors, promoting entry into target cell types. In the present study, the integration of GM3-MIM into the peptide nanofiber structure enabled efficient internalization of the molecule. Considering that highly mannosylated structures are suitable candidates for DC-SIGN receptor targeting, using sugar moieties for delivery purposes hold high potential for future studies.

\section{EXPERIMENTAL SECTION}

Materials. 9-Fluorenylmethoxycarbonyl (Fmoc) protected amino acids, [4-[ $\alpha$ - $\left(2^{\prime}, 4^{\prime}\right.$-dimethoxyphenyl $)$ Fmoc aminomethyl] phenoxy] acetamidonorleucyl-MBHA resin (Rink amide MBHA resin) and 2-(1H-benzotriazol-1-yl)-1,1,3,3-tetramethyluronium hexafluorophosphate (HBTU) were purchased from NovaBiochem. Fmoc-Ser $[\beta$-D$\left.\mathrm{Glc}(\mathrm{OAc})_{4}\right]-\mathrm{OH}$ was purchased from AAPPTec. Lauric acid and $\mathrm{N}, \mathrm{N}$ - diisopropylethylamine (DIEA) were purchased from Merck. Other chemicals were purchased from Alfa Aesar or Sigma-Aldrich and used without any purification. Deionized water (resistance of $18 \mathrm{M} \Omega \mathrm{cm}$ ) was used during the experiments.

Synthesis of N-(9-Fluorenylmethoxycarbonyl)-L-serine allyl ester (3). Protection of the carboxylic acid of Fmoc-Ser-OH to produce Fmoc-L-Ser-OAll resulted in $86 \%$ yield. Fmoc-Ser-OH (1) (1.5 g, $4.5 \mathrm{mmol}$ ) was dissolved in DMF and mixed with allyl bromide $(2.14 \mathrm{~mL}, 5.4 \mathrm{mmol})$ in the presence of $\mathrm{K}_{2} \mathrm{CO}_{3}(0.93 \mathrm{~g}, 6.75 \mathrm{mmol})$. The reaction was allowed to stay for $24 \mathrm{~h}$ at room temperature. After $\mathrm{CH}_{2} \mathrm{Cl}_{2}$ addition, the mixture was extracted with water and brine solution. Aqueous phase was discarded and $\mathrm{Na}_{2} \mathrm{SO}_{4}$ was added into organic phase. The solution was concentrated with rotary evaporator and purified using flash column chromatography (1:1 nHex/EtOAc). ${ }^{1} \mathrm{H} \operatorname{NMR}\left(400 \mathrm{MHz}, \mathrm{CDCl}_{3}\right) \delta(\mathrm{ppm})=7.79(\mathrm{~d}, J=7.5 \mathrm{~Hz}, 2 \mathrm{H}), 7.63$ $(\mathrm{d}, J=6.7 \mathrm{~Hz}, 2 \mathrm{H}), 7.43(\mathrm{t}, J=7.5 \mathrm{~Hz}, 2 \mathrm{H}), 7.34(\mathrm{tt}, J=1.1,7.5 \mathrm{~Hz}$, $2 \mathrm{H}), 6.02-5.85(\mathrm{~m}, 1 \mathrm{H}), 5.75(\mathrm{~d}, J=6.0 \mathrm{~Hz}, 1 \mathrm{H}), 5.37(\mathrm{dd}, J=1.1$ $17.2 \mathrm{~Hz}, 1 \mathrm{H}), 5.29(\mathrm{dd}, J=1.1,10.4 \mathrm{~Hz}, 1 \mathrm{H}), 4.72(\mathrm{~d}, J=2.3 \mathrm{~Hz}, 1 \mathrm{H})$, $4.55-4.41(\mathrm{~m}, 3 \mathrm{H}), 4.26(\mathrm{t}, J=6.9 \mathrm{~Hz}, 1 \mathrm{H}), 4.10-3.92(\mathrm{~m}, 2 \mathrm{H}) .{ }^{13} \mathrm{C}$ $\operatorname{NMR}\left(100 \mathrm{MHz}, \mathrm{CDCl}_{3}\right) \delta(\mathrm{ppm})=1700.12,156.23,143.69,141.37$, $141.33,131.32,127.75,127.10,125.06,119.99$, 119.04, 67.22, 66.36, $61.89,56.13,47.19$. NMR data were in agreement with those reported
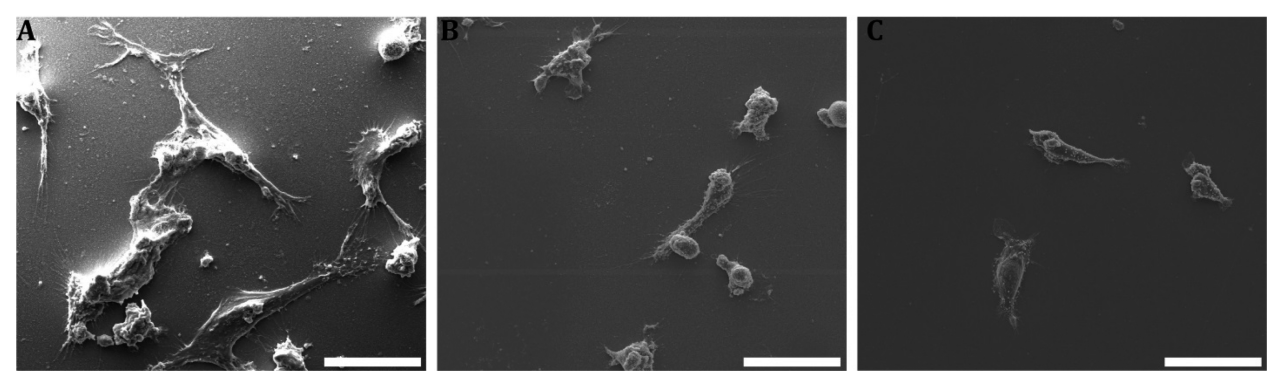

Figure 6. Morphological analyses of the differentiation in iDCs when treated with (A) Man-PA/GM3-MIM, (B) Glc-PA/GM3-MIM, and (C) GM3-MIM for $24 \mathrm{~h}$. Scale bars are $30 \mu \mathrm{m}$. 
in the literature. ${ }^{39}$ ESI-TOF-HR-MS $\mathrm{m} / z$ calcd for $\mathrm{C}_{21} \mathrm{H}_{21} \mathrm{NO}_{5}$ $[\mathrm{M}+\mathrm{Na}]^{+}$390.1420; found 390.1363, $[2 \mathrm{M}+\mathrm{Na}]^{+}$757.2814.

Synthesis of 1,2,3,4,6-Penta-O-acetyl-D-mannopyranose (4). Acetylation of D-mannose resulted in $93 \%$ yield. Three grams of D-mannose (2) (1 equiv.) was dissolved in pyridine $(4 \mathrm{~mL})$ and $15 \mathrm{~mL}$ of acetic anhydride (10 equiv.) was added into the solution. The reaction was kept at room temperature and stirred overnight. Pyridine was evaporated and kept under vacuum for $3-4 \mathrm{~h}$. The product was purified by column chromatography $(1: 1 \mathrm{n}$-Hex:EtOAc, $\mathrm{Rf}=0.45)$ ${ }^{1} \mathrm{H}$ NMR (400 MHz, $\mathrm{CDCl}_{3}$, mixture of both anomers): signals of $\beta$-anomer $\delta(\mathrm{ppm})=6.11(\mathrm{~d}, J=1.8 \mathrm{~Hz}, 1 \mathrm{H}), 5.38-5.36(\mathrm{~m}, 2 \mathrm{H})$, $5.28(\mathrm{~d}, J=2.0 \mathrm{~Hz}, 1 \mathrm{H}), 4.30(\mathrm{dd}, J=4.9,12.4 \mathrm{~Hz}, 1 \mathrm{H}), 4.18-4.15$ $(\mathrm{m}, 1 \mathrm{H}), 4.08(\mathrm{dd}, J=2.4,12.4 \mathrm{~Hz}, 1 \mathrm{H}), 2.20(\mathrm{~s}, 3 \mathrm{H}), 2.19(\mathrm{~s}, 3 \mathrm{H})$, $2.11(\mathrm{~s}, 3 \mathrm{H}), 2.07(\mathrm{~s}, 3 \mathrm{H}), 2.03(\mathrm{~s}, 3 \mathrm{H})$; signals of $\alpha$-anomer $\delta(\mathrm{ppm})=5.87(\mathrm{~d}, J=1.2 \mathrm{~Hz}, 1 \mathrm{H}), 5.51(\mathrm{dd}, J=1.1,3.3 \mathrm{~Hz}, 1 \mathrm{H})$, $5.31(\mathrm{t}, J=10.0 \mathrm{~Hz}, 1 \mathrm{H}), 5.15(\mathrm{dd}, J=3.3,10.0 \mathrm{~Hz}, 1 \mathrm{H}), 4.32(\mathrm{dd}$, $J=5.3,12.4 \mathrm{~Hz}, 1 \mathrm{H}), 4.07(\mathrm{dd}, J=2.4,12.4 \mathrm{~Hz}, 1 \mathrm{H}), 3.83(\mathrm{ddd}, J=$ 2.4, 5.3, $9.8 \mathrm{~Hz}, 1 \mathrm{H}), 2.19(\mathrm{~s}, 3 \mathrm{H}), 2.12(\mathrm{~s}, 3 \mathrm{H}), 2.07(\mathrm{~s}, 3 \mathrm{H}), 2.06$ (s, $3 \mathrm{H}), 2.02(\mathrm{~s}, 3 \mathrm{H}) ;{ }^{13} \mathrm{C}$ NMR $\left(100 \mathrm{MHz}, \mathrm{CDCl}_{3}\right.$, mixture of both anomers) $\delta(\mathrm{ppm})=170.58,170.14,169.93,169.68,169.53,169.49$, 168.00, 90.64, 90.44, 73.34, 70.65, 68.75, 68.36, 68.19, 65.81, 65.61, $65.48,62.13,62.09,21.00,20.81,20.71,20.70,20.67,20.66,20.62$, $20.61,20.59,20.49$. NMR data were in agreement with those reported in the literature. ${ }^{40}$ ESI-TOF-HRMS $\mathrm{m} / z$ calculated for $\mathrm{C}_{16} \mathrm{H}_{22} \mathrm{O}_{11}$ $[\mathrm{M}+\mathrm{Na}]^{+}$413.1162; found 413.1064 .

Synthesis of N-(9-Fluorenylmethoxycarbonyl)-3-O-(2,3,4,6-tetraO-acetyl- $\alpha$-D-mannopyranosyl)-L-serine Allyl Ester (5). D-Mannose pentaacetate coupling to Fmoc-L-Ser-O. All to produce Fmoc-L$\operatorname{Ser}\left[\alpha\right.$-D-Man $\left.\left(\mathrm{OAc}_{4}\right)\right]$-O. All resulted in $40 \%$ yield. The Lewis acid, $\mathrm{BF}_{3} \cdot \mathrm{Et}_{2} \mathrm{O}(8 \mathrm{~mL}, 0.3 \mathrm{mmol})$, was added to the mannose pentaacetate (4) (1.3 equiv., $4 \mathrm{~g}$ ) and $\mathrm{N}-\alpha$-Fmoc-Ser-OAll (3) (1 equiv., $2.9 \mathrm{~g}$ ) in dry $\mathrm{CH}_{2} \mathrm{Cl}_{2}$ under argon atmosphere. The reaction was cooled to $0{ }^{\circ} \mathrm{C}$ for Lewis acid addition, after 5-10 min reaction was allowed to stay at room temperature for $12 \mathrm{~h}$. The progress of the glycosylation reaction was monitored by TLC $(2: 3 \mathrm{nHex} / \mathrm{EtOAc})$. The solution was diluted with $\mathrm{CH}_{2} \mathrm{Cl}_{2}$ and extraction was done with water (3 times). $\mathrm{Na}_{2} \mathrm{SO}_{4}$ was added to remove trace amounts of water and the solution was concentrated in a rotary evaporator. Compound was purified with column chromatography $(2: 3 \mathrm{nHex} / \mathrm{EtOAc}, \mathrm{Rf}=0.3) .{ }^{1} \mathrm{H}$ NMR $\left(400 \mathrm{MHz}, \mathrm{CDCl}_{3}\right) \delta(\mathrm{ppm})=7.79(\mathrm{~d}, J=7.5 \mathrm{~Hz}, 2 \mathrm{H}), 7.65(\mathrm{~d}, J=$ $7.3 \mathrm{~Hz}, 2 \mathrm{H}), 7.42(\mathrm{t}, J=7.3 \mathrm{~Hz}, 2 \mathrm{H}), 7.34(\mathrm{t}, J=7.4 \mathrm{~Hz}, 2 \mathrm{H}), 6.01-$ $5.92(\mathrm{~m}, 1 \mathrm{H}), 5.90(\mathrm{~d}, J=7.8 \mathrm{~Hz}, 1 \mathrm{H}), 5.39-5.36(\mathrm{~m}, 1 \mathrm{H}), 5.34-5.27$ (m, 3H), 5.22 (brs, $1 \mathrm{H}), 4.82(\mathrm{~s}, 1 \mathrm{H}), 4.77-4.69(\mathrm{~m}, 2 \mathrm{H}), 4.65-4.60$ (m, $1 \mathrm{H}), 4.43(\mathrm{~d}, J=7.1 \mathrm{~Hz}, 2 \mathrm{H}), 4.29-4.23(\mathrm{~m}, 2 \mathrm{H}), 4.15-4.12(\mathrm{~m}$, $1 \mathrm{H}), 4.11-4.07(\mathrm{~m}, 1 \mathrm{H}), 4.04-3.97(\mathrm{~m}, 2 \mathrm{H}), 2.19(\mathrm{~s}, 3 \mathrm{H}), 2.09(\mathrm{~s}$, 3H), 2.04 (s, 3H), 2.01 (s, 3H). ${ }^{13} \mathrm{C}$ NMR (100 MHz, $\left.\mathrm{CDCl}_{3}\right) \delta$ $(\mathrm{ppm})=170.57,169.91,169.75,169.69,155.84,148.98,148.28$, 143.77, 141.30, 131.24, 127.92, 127.76, 127.11, 125.15, 120.32, 120.01, $119.55,98.58,90.62,70.63,69.68,69.19,68.78,68.35,66.62,65.98$, $62.35,62.12,60.37,54.43,47.11,20.82,20.68,20.65,20.63$. NMR data were in agreement with those reported in the literature. ${ }^{41}$ ESI-TOFHRMS $m / z$ calculated for $\mathrm{C}_{35} \mathrm{H}_{39} \mathrm{NO}_{14}[\mathrm{M}+\mathrm{H}]^{+}$698.2371; found 698.2002, $[\mathrm{M}+\mathrm{Na}]^{+} 720.1802,[\mathrm{M}+\mathrm{K}]^{+} 736.1543$.

Synthesis of N-(9-Fluorenylmethoxycarbonyl)-3-O-(2,3,4,6-tetra$O$-acetyl- $\alpha$-D-mannopyranosyl)-L-serine (6). Deprotection of allyl group for production of Fmoc-L-Ser $\left[\alpha-\mathrm{Man}(\mathrm{OAc})_{4}\right]-\mathrm{OH}$ resulted in $72 \%$ yield. Glycosylated amino acid (5) $(4.02 \mathrm{mmol}, 2.8 \mathrm{~g})$, $\mathrm{N}$-methylaniline $(40.68 \mathrm{mmol}, 4.40 \mathrm{~mL})$, and $\mathrm{Pd}\left(\mathrm{PPh}_{3}\right)_{4}(0.048 \mathrm{mmol}$, $55 \mathrm{mg}$ ) were dissolved in THF. The reaction took place at room temperature under argon overnight and monitored with TLC (98:2, DCM:AcOH). The compound was concentrated with rotary evaporator and the product was purified with column chromatography $(1: 1 \mathrm{nHex} /$ EtOAc $) .{ }^{1} \mathrm{H}$ NMR $\left(400 \mathrm{MHz}, \mathrm{CDCl}_{3}\right) \delta(\mathrm{ppm})=7.78(\mathrm{~d}$, $J=7.5 \mathrm{~Hz}, 2 \mathrm{H}), 7.63(\mathrm{t}, J=6.7 \mathrm{~Hz}, 2 \mathrm{H}), 7.41(\mathrm{t}, J=7.4 \mathrm{~Hz}, 2 \mathrm{H}), 7.32$ $(\mathrm{t}, \mathrm{J}=7.4 \mathrm{~Hz}, 2 \mathrm{H}), 6.46(\mathrm{~d}, J=7.7 \mathrm{~Hz}, 1 \mathrm{H}), 5.45(\mathrm{dd}, J=3.0,10.0 \mathrm{~Hz}$, $1 \mathrm{H}), 5.33-5.25(\mathrm{~m}, 2 \mathrm{H}), 4.88(\mathrm{brs}, 1 \mathrm{H}), 4.71(\mathrm{~d}, J=8.0 \mathrm{~Hz}, 1 \mathrm{H}), 4.45$ (dd, $J=7.5,10.4 \mathrm{~Hz}, 1 \mathrm{H}), 4.39-4.33(\mathrm{~m}, 1 \mathrm{H}), 4.29(\mathrm{~d}, J=5.5 \mathrm{~Hz}$, $1 \mathrm{H}), 4.27-4.21(\mathrm{~m}, 2 \mathrm{H}), 4.18-4.12(\mathrm{~m}, 2 \mathrm{H}), 4.10-4.06(\mathrm{~m}, 2 \mathrm{H})$, $2.18(\mathrm{~s}, 3 \mathrm{H}), 2.08(\mathrm{~s}, 3 \mathrm{H}), 2.04(\mathrm{~s}, 3 \mathrm{H}), 2.00(\mathrm{~s}, 3 \mathrm{H})) .{ }^{13} \mathrm{C}$ NMR $\left(100 \mathrm{MHz}, \mathrm{CDCl}_{3}\right) \delta(\mathrm{ppm})=171.82,170.73,170.68,170.20$,
$169.82,156.03,143.81,143.76,141.30,141.28,127.93,127.74,127.09$, $125.22,125.15,121.48,120.33,120.00,98.13,69.40,69.34,69.02$, $68.93,67.34,66.16,62.33,54.05,47.12,20.85,20.79,20.67,20.62$. NMR data were in agreement with those reported in the literature. ${ }^{41}$ ESI-TOF-HRMS $m / z$ calculated for $\mathrm{C}_{32} \mathrm{H}_{35} \mathrm{NO}_{14}[\mathrm{M}-\mathrm{H}]^{-}$656.2058; found 656.1897, $[2 \mathrm{M}-\mathrm{H}]^{-}$1313.3849.

Synthesis of Amphiphilic Glycopeptides. Protected glycopeptides (Man-PA and Glc-PA) were constructed on MHBA Rink Amide resin. All amino acid couplings were performed with 2 equiv of Fmoc protected amino acid, 1.95 equiv of HBTU and 3 equiv of $\mathrm{N}, \mathrm{N}$-diisopropylethylamine (DIEA) in DMF for $3 \mathrm{~h}$. Fmoc removals were performed with $20 \%$ piperidine/dimethylformamide (DMF) solution for $20 \mathrm{~min}$. Cleavage of the peptides from the resin and deprotection of acid labile protecting groups were carried out with a mixture of trifluoroacetic acid (TFA):triisopropyl silane (TIS):water in the ratio of 95:2.5:2.5 for $2 \mathrm{~h}$. Excess TFA was removed by rotary evaporation. The remaining residue was triturated with ice-cold diethyl ether and the resulting white pellet was freeze-dried. Deacetylation reaction was carried out in solution. For the cleavage of acetyl groups, $210 \mathrm{mg}$ of protected glycopeptide (1 equiv.) was dissolved in $105 \mathrm{~mL}$ of anhydrous methanol. Two moles of $\mathrm{NaOMe} \mathrm{(4.4} \mathrm{equiv.)} \mathrm{was}$ dissolved in methanol and poured into the solution. After adjusting $\mathrm{pH}$ to $8-8.5$, the reaction was carried out at room temperature for $2-3 \mathrm{~h}$. The solution was neutralized with a few drops of acetic acid in order to terminate the reaction. The solvent was removed by vacuum. After water addition, it was frozen at $-80{ }^{\circ} \mathrm{C}$ and freeze-dried. Before and after the deacetylation reaction, glycopeptides were identified and analyzed by reverse phase HPLC on an Agilent 6530 accurate-Mass Q-TOF LC/MS equipped with an Agilent 1200 HPLC. A Phenomenex Luna C8 100A $(50 \times 3.00 \mathrm{~mm})$ column as stationary phase and water/acetonitrile gradient with $0.1 \%$ formic acid as mobile phase were used to identify the peptide amphiphile. They were purified on Agilent 1200 by using a Zorbax prepHT 300CB-C 8 column with a water-acetonitrile (0.1\% TFA) gradient.

Synthesis of Fluorescent GM3-MIM ® (GM3-MIM-BODIPY). The alkyl derivative of GM3-MIM was prepared according to the previously reported procedure. ${ }^{42}$ For the synthesis of the fluorescent derivative of GM3-MIM, the procedure is described below: To a stirred solution of amino alkyl MIM-GM3 $(17.8 \mathrm{mg}, 0.037 \mathrm{mmol})$ in a mixture of DMF: $\mathrm{H}_{2} \mathrm{O}(4: 1,1 \mathrm{~mL})$ were added $\mathrm{NaHCO}_{3}(4.3 \mathrm{mg}$, $0.052 \mathrm{mmol})$ and BODIPY-NHS ester $(20.2 \mathrm{mg}, 0.052 \mathrm{mmol})$. The reaction mixture was stirred for $18 \mathrm{~h}$ at room temperature, then concentrated to dryness. The crude was purified by flash chromatography on silica gel (eluent: $\mathrm{CH}_{2} \mathrm{Cl}_{2}: \mathrm{MeOH} 5: 1$ ) to afford GM3-MIMBODIPY as a glassy brown solid $(24.0 \mathrm{mg}, 0.032 \mathrm{mmol}, 86 \%) .[\alpha]_{\mathrm{D}}{ }^{22}=$ $-54.3\left(c 0.41, \mathrm{CH}_{3} \mathrm{OH}\right) ;{ }^{1} \mathrm{H}$ NMR $\left(500 \mathrm{MHz}, \mathrm{CD}_{3} \mathrm{OD}\right) \delta 7.44(\mathrm{~s}$, H-b8), 7.03 (d, $J=3.9 \mathrm{~Hz}, \mathrm{H}-\mathrm{b} 2), 6.34$ (d, $J=3.9 \mathrm{~Hz}, \mathrm{H}-\mathrm{b} 3$ ), 6.23 (s, H-b6), 4.98 (s, H-a), 4.18-4.15 (m, H-3), 4.10-4.08 (m, H-e), 4.04 $(\mathrm{ad}, J=2.2 \mathrm{~Hz}, \mathrm{H}-4), 3.96(\mathrm{ad}, J=9.6 \mathrm{~Hz}, \mathrm{H}-5), 3.83-3-64(\mathrm{~m}, 7 \mathrm{H}$, $\left.\mathrm{H}-\mathrm{x}_{a}, \mathrm{H}-\mathrm{f}, \mathrm{H}-\mathrm{d}, \mathrm{H}-6, \mathrm{H}-7\right), 3.52-3.47(\mathrm{~m}, 1 \mathrm{H}, \mathrm{H}-\mathrm{xb}), 3.24(\mathrm{t}, J=$ $7.5 \mathrm{~Hz}, 2 \mathrm{H}, \mathrm{H}-\mathrm{w}$ ), 3.19 (t, J = 6.8 Hz, 2H, H-y), 3.04-3.02 (part A of an $A B$ system, $J_{A-B}=12.8 \mathrm{~Hz}, \mathrm{H}-1$ 'a), 3.0-2.97 (part $B$ of an $A B$ system, $\left.J_{\mathrm{B}-\mathrm{A}}=12.8 \mathrm{~Hz}, \mathrm{H}-\mathrm{l}^{\prime} \mathrm{b}\right), 2.62(\mathrm{t}, \mathrm{J}=7.5 \mathrm{~Hz}, 2 \mathrm{H}, \mathrm{H}-\mathrm{z}), 2.53(\mathrm{~s}$, $\left.3 \mathrm{H}, \mathrm{CH}_{3}\right), 2.30\left(\mathrm{~s}, 3 \mathrm{H}, \mathrm{CH}_{3}\right), 1.95-1.93(\mathrm{~m}, 2 \mathrm{H}, \mathrm{H}-2), 1.63-1.30(\mathrm{~m}$, $\left.8 \mathrm{H}, \mathrm{CH}_{2}\right) .{ }^{13} \mathrm{C}$ NMR $\left(125 \mathrm{MHz}, \mathrm{CD}_{3} \mathrm{OD}\right) \delta 173.1(\mathrm{Cq}), 159.9(\mathrm{Cq})$, $157.1(\mathrm{Cq}), 144.4(\mathrm{Cq}), 141.8(\mathrm{Cq}), 135.1(\mathrm{Cq}), 133.5(\mathrm{Cq}), 128.2$ (C-b1), 124.4 (C-b8), 119.9 (C-b6), 116.3 (C-b2), 106.4 (Cq), 96.3 (C-a), 92.3 (C-1), 72.5 (C-e), 70.9 (C-5), 68.4 (C-d), 67.8 (C-x), 66.4 (C-4), 66.2 (C-3), 64.5 (C-6), 62.8 (C-7), 61.0 (C-f), 39.0 (C-y), 36.2 (C-2), 34.7 (C-w), 33.2 (C-1'), 29.1, 28.9, 26.3, $25.6\left(\mathrm{CH}_{2}\right), 24.3$ (C-z), 13.5, $9.8\left(\mathrm{CH}_{3}\right)$; HRMS: $m / z$ calcd for $\mathrm{C}_{34} \mathrm{H}_{47} \mathrm{O}_{11} \mathrm{~N}_{3} \mathrm{BF}_{2} \mathrm{~S}$ $[\mathrm{M}-\mathrm{H}]^{-}$753.30274, found 753.30342. Characterizations of fluorescent GM3-MIM (GM3-MIM-BODIPY) are shown in Figures S10-S12.

Preparation of Fluorescent GM3-MIM Integrated Glycopeptide Nanofibers. One $\mathrm{mM}$ of Man-PA and Glc-PA (2 mL) were dissolved in water and heated up to $50{ }^{\circ} \mathrm{C}$ during sonication. $1.33 \mathrm{mM}$ of GM3-MIM was dissolved in DCM:MeOH mixture (7:1 v/v \%, $610 \mu \mathrm{L})$ and added into each glycopeptide solution. They were sonicated and vortexed for an hour at $50{ }^{\circ} \mathrm{C}$. Although the mixture was initially turbid, it became transparent as the solvents evaporated. 
Final GM3-MIM concentration to PA concentration ratio was adjusted to $1: 2.5$.

Characterization of Fluorescent GM3-MIM Integrated Glycopeptide Nanofibers. Fluorescence spectra of GM3-MIM and GM3-MIM integrated glycopeptide nanofibers were recorded by a Varian Cary Eclipse spectrophotometer with an excitation wavelength of $503 \mathrm{~nm}$. Varian Cary $100 \mathrm{UV}$-vis spectrophotometer was used to record absorption spectra of GM3-MIM-BODIPY and GM3-MIM integrated glycopeptide nanofibers. For UV and fluorescence measurements, DCM:MeOH mixture (7:1, v/v \%) was used to dissolve GM3MIM-BODIPY, and water was used as the solvent for GM3-MIM integrated glycopeptide nanofibers. A Jasco J-815 CD spectrophotometer was used to investigate the secondary structures of PA molecules and GM3-MIM integrated PA nanofibers. All samples were measured at physiological $\mathrm{pH}$ at $0.25 \mathrm{mM}$ concentration. $300 \mu \mathrm{L}$ of the sample was transferred into a $1 \mathrm{~mm}$ quartz cuvette and spectra were obtained at room temperature from 300 to $190 \mathrm{~nm}$ with a data interval of $1 \mathrm{~nm}$ and a scanning speed of $100 \mathrm{~nm} / \mathrm{min}$. TEM images were obtained with a FEI Tecnai G2 F30 TEM at $200 \mathrm{kV}$. A high-angle annular dark field (HAADF) detector was used for images taken in STEM mode. One mM of Glc-PA, Man-PA and GM3-MIM integrated glycopeptide nanofiber systems were first diluted to $150 \mu \mathrm{M}$ and then dropped on 300-mesh carbon TEM grids. Samples were allowed to stay at room temperature for $3 \mathrm{~min}$, stained by $2 \mathrm{wt} \%$ uranyl-acetate staining for another 1-2 min and air-dried prior to STEM imaging. Zeta potential of the nanofibers was measured by ZetaSizer. A Malvern Nanosizer/ZetaSizer Nano-ZS ZEN 3600 (Malvern Instruments, USA) instrument was used for the analysis. Measurements were performed in quartz cuvettes and repeated at least three times. Samples were prepared by dissolving each component in water at a concentration of $0.25 \mathrm{mM}$.

Cellular Viability. THP-1 human monocytes were kindly provided by Prof. E. Erbay of Bilkent University. Cells were seeded onto 96 well plates at a density of 5000 cells/well within media containing Man-PA and Glc-PA. Viability was assessed at $150 \mu \mathrm{M}$ and $250 \mu \mathrm{M}$ for both peptide molecules. At the end of $24 \mathrm{~h}$, cells were washed with $1 \times \mathrm{PBS}$ and were stained with Calcein-AM and ethidium homodimer for $30 \mathrm{~min}$ at room temperature in dark. Then, images of the cells were taken and quantified by using Image J program.

Differentiation of THP-1 Human Monocytes into Immature Dendritic Cells. THP-1 human monocyte cell line was differentiated into immature dendritic cells in RPMI medium containing 10\% FBS, rhIL-4 $(100 \mathrm{ng} / \mathrm{mL})$, and rhGM-CSF $(100 \mathrm{ng} / \mathrm{mL})$ for 5 days. Medium was exchanged with fresh cytokines after 2 days.

Internalization of Fluorescent GM3-MIM Integrated Glycopeptide Nanofibers. Thirteen $\mathrm{mm}$ glass coverslips were placed in 24-well plates and $5 \times 10^{4} \mathrm{THP}-1$ cells were seeded and differentiated into immature dendritic cells as previously stated. After 5 days, the PA molecules were administered and cells were incubated for $24 \mathrm{~h}$. After incubation, cells were washed with PBS two times, fixed with $4 \%$ paraformaldehyde, and permeabilized with $3 \%$ Triton- $X$ and stained with phalloidin and TO-PRO-3. Cells were visualized by using Laser Scanning Confocal Microscope (LSM 510, Zeiss).

Surface Marker Analyses of Dendritic Cell Activation. iDCs were obtained from THP-1 monocytes as mentioned above. At the end of 5 days, cells were treated with Man-PA, Glc-PA, Man-PA/ GM3-MIM, Glc-PA/GM3-MIM, and only GM3-MIM for $24 \mathrm{~h}$. Total peptide concentration for each group was $150 \mu \mathrm{M}$ and GM3-MIM amount was $40 \mu \mathrm{g}$. At the end of $24 \mathrm{~h}$, media were discarded, cells were centrifuged at $2500 \mathrm{rpm}$ for $5 \mathrm{~min}$ and washed with $1 \times$ PBS and then centrifuged again. Then, pellet was dissolved in $1 \times$ PBS and cells were stained with CD86 (PerCP), CD83 (Phycoerythrin) and HLA-DR (MHC-II) (PE/Cy5) antibodies for $15 \mathrm{~min}$ at room temperature. 10000 cells were recorded for each condition during flow cytometry analyses.

Scanning Electron Microscopy (SEM) Imaging. SEM imaging was carried out in order to evaluate the morphological changes during dendritic cell maturation. $5 \times 10^{4}$ THP- 1 cells were seeded onto coverslips in 24-well plates and differentiated into immature DCs as previously stated. Treatment was carried out for $24 \mathrm{~h}$ and at the end of $24 \mathrm{~h}$ cells were washed once with $1 \times$ PBS, fixed with $2 \%$ gluteraldehyde/PBS and $1 \mathrm{wt} \% \mathrm{OsO}_{4}$ for $1 \mathrm{~h}$ each. After fixation, cells were washed with $\mathrm{ddH}_{2} \mathrm{O}$ and dehydrated by using increasing ethanol concentrations; 20, 40,60,80, and $100 \% \mathrm{v} / \mathrm{v}$. Critical point dryer (Autosamdri $815 \mathrm{~B}$ equipment from Tousimis) was used afterward and coverslips were coated with $4 \mathrm{~nm} \mathrm{Au} / \mathrm{Pd}$. SEM (FEI Quanta 200 FEG) images were taken through using Everhart-Thornley Detector (ETD) at high vacuum mode at $5 \mathrm{keV}$ beam energy.

\section{ASSOCIATED CONTENT}

\section{Supporting Information}

The Supporting Information is available free of charge on the ACS Publications website at DOI: 10.1021/acsami.7b04094.

Synthesis details, ${ }^{1} \mathrm{H}$ NMR and ${ }^{13} \mathrm{C}$ NMR spectra, HR-MS spectra, liquid chromatograms and mass spectra (LC-MS) of amphiphilic glycopeptides, CD spectra of amphiphilic glycopeptides, STEM images of glyco-PAs, TEM mapping of fluorescent GM3-MIM integration, zeta potentials of glyco-PAs, Live-Dead assay for glycoPAs, THP-1 differentiation into iDC, flow cytometry, SEM images (PDF)

\section{AUTHOR INFORMATION}

\section{Corresponding Authors}

*E-mail: mguler@uchicago.edu (M.O.G.).

*E-mail: atekinay@unam.bilkent.edu.tr (A.B.T.).

*E-mail: cristina.nativi@unifi.it (C.N.).

ORCID

Cristina Nativi: 0000-0002-6312-3230

Ayse B. Tekinay: 0000-0002-4453-814X

Mustafa O. Guler: 0000-0003-1168-202X

\section{Author Contributions}

${ }^{\dagger}$ G.G. and M.S.E. contributed equally to this work.

\section{Funding}

G.G. acknowledge support from TUBITAK-BIDEB 2210-C fellowship. This work was partially supported by TUBITAK, TUBA, and by AIRC (Italy).

\section{Notes}

The authors declare no competing financial interest.

\section{ACKNOWLEDGMENTS}

The authors thank Dr. A. Shaikh for the help in glycosylated amino acid synthesis, M. Guler for help with TEM imaging, Dr. Hamid Muhammed Syed for help in THP-1 culturing, and Alper D. Ozkan for scientific discussion.

\section{REFERENCES}

(1) Rabinovich, G. A.; Gabrilovich, D.; Sotomayor, E. M. Immunosuppressive Strategies That Are Mediated by Tumor Cells. Annu. Rev. Immunol. 2007, 25, 267.

(2) Pardoll, D. M. The Blockade of Immune Checkpoints in Cancer Immunotherapy. Nat. Rev. Cancer 2012, 12 (4), 252-264.

(3) Croci, D. O.; Fluck, M. F. Z.; Rico, M. J.; Matar, P.; Rabinovich, G. A.; Scharovsky, O. G. Dynamic Cross-Talk between Tumor and Immune Cells in Orchestrating the Immunosuppressive Network at the Tumor Microenvironment. Cancer Immunol. Immunother. 2007, 56 (11), 1687-1700.

(4) Steinman, R. M.; Cohn, Z. A. Identification of a Novel Cell Type in Peripheral Lymphoid Organs of Mice I. Morphology, Quantitation, Tissue Distribution. J. Exp. Med. 1973, 137 (5), 1142-1162.

(5) Comabella, M.; Montalban, X.; Münz, C.; Lünemann, J. D. Targeting Dendritic Cells to Treat Multiple Sclerosis. Nat. Rev. Neurol. 2010, 6 (9), 499-507. 
(6) Banchereau, J.; Steinman, R. M. Dendritic Cells and the Control of Immunity. Nature 1998, 392 (6673), 245-252.

(7) Bretscher, P. The Two-Signal Model of Lymphocyte Activation Twenty-One Years Later. Immunol. Today 1992, 13 (2), 74-76.

(8) Stockwin, L. H.; McGONAGLE, D.; Martin, I. G.; Blair, G. E. Dendritic Cells: Immunological Sentinels with a Central Role in Health and Disease. Immunol. Cell Biol. 2000, 78 (2), 91-102.

(9) Zelensky, A. N.; Gready, J. GE. The C-Type Lectin-Like Domain Superfamily. FEBS J. 2005, 272 (24), 6179-6217.

(10) Park, C. G. Vaccine Strategies Utilizing C-Type Lectin Receptors on Dendritic Cells in Vivo. Clin. Exp. Vaccine Res. 2014, 3 (2), 149-154.

(11) Soilleux, E. J.; Morris, L. S.; Leslie, G.; Chehimi, J.; Luo, Q.; Levroney, E.; Trowsdale, J.; Montaner, L. J.; Doms, R. W.; Weissman, D. Constitutive and Induced Expression of DC-SIGN on Dendritic Cell and Macrophage Subpopulations in Situ and in Vitro. J. Leukoc. Biol. 2002, 71 (3), 445-457.

(12) Figdor, C. G.; van Kooyk, Y.; Adema, G. J. C-Type Lectin Receptors on Dendritic Cells and Langerhans Cells. Nat. Rev. Immunol. 2002, 2 (2), 77-84.

(13) Mitchell, D. A.; Fadden, A. J.; Drickamer, K. A Novel Mechanism of Carbohydrate Recognition by the C-Type Lectins DC-SIGN and DC-SIGNR Subunit Organization and Binding to Multivalent Ligands. J. Biol. Chem. 2001, 276 (31), 28939-28945.

(14) Hong, P. W.-P.; Flummerfelt, K. B.; de Parseval, A.; Gurney, K.; Elder, J. H.; Lee, B. Human Immunodeficiency Virus Envelope (Gp120) Binding to DC-SIGN and Primary Dendritic Cells Is Carbohydrate Dependent but Does Not Involve 2G12 or Cyanovirin Binding Sites: Implications for Structural Analyses of Gp120-DCSIGN Binding. J. Virol. 2002, 76 (24), 12855-12865.

(15) Ribeiro-Viana, R.; Bonechi, E.; Rojo, J.; Ballerini, C.; Comito, G.; Richichi, B.; Nativi, C. Human Dendritic Cell Activation Induced by a Permannosylated Dendron Containing an Antigenic GM3Lactone Mimetic. Beilstein J. Org. Chem. 2014, 10 (1), 1317-1324.

(16) Varga, N.; Sutkeviciute, I.; Guzzi, C.; McGeagh, J.; PetitHaertlein, I.; Gugliotta, S.; Weiser, J.; Angulo, J.; Fieschi, F.; Bernardi, A. Selective Targeting of Dendritic Cell-Specific Intercellular Adhesion Molecule-3-Grabbing Nonintegrin (DC-SIGN) with Mannose-Based Glycomimetics: Synthesis and Interaction Studies of Bis (Benzylamide) Derivatives of a Pseudomannobioside. Chem. - Eur. J. 2013, 19 (15), 4786-4797.

(17) van Liempt, E.; Bank, C.; Mehta, P.; Kawar, Z. S.; Geyer, R.; Alvarez, R. A.; Cummings, R. D.; Kooyk, Y. v.; van Die, I. Specificity of DC-SIGN for Mannose-and Fucose-Containing Glycans. FEBS Lett. 2006, 580 (26), 6123-6131.

(18) Renkvist, N.; Castelli, C.; Robbins, P. F.; Parmiani, G. A Listing of Human Tumor Antigens Recognized by T Cells. Cancer Immunol. Immunother. 2001, 50 (1), 3-15.

(19) Wang, R.-F. Tumor Antigens Discovery: Perspectives for Cancer Therapy. Mol. Med. 1997, 3 (11), 716.

(20) Mansh, M. Ipilimumab and Cancer Immunotherapy: A New Hope for Advanced Stage Melanoma. Yale J. Biol. Med. 2011, 84 (4), 381-389.

(21) Mazorra, Z.; Mesa, C.; Fernández, L. E. GM3 Ganglioside: A Novel Target for the Therapy against Melanoma. Biotecnol. Apl. 2009, 26 (3), 256-259.

(22) Cruz, L. J.; Rueda, F.; Cordobilla, B.; Simón, L.; Hosta, L.; Albericio, F.; Domingo, J. C. Targeting Nanosystems to Human DCs Via Fc Receptor as an Effective Strategy to Deliver Antigen for Immunotherapy. Mol. Pharmaceutics 2011, 8 (1), 104-116.

(23) Cruz, L. J.; Tacken, P. J.; Fokkink, R.; Figdor, C. G. The Influence of Peg Chain Length and Targeting Moiety on AntibodyMediated Delivery of Nanoparticle Vaccines to Human Dendritic Cells. Biomaterials 2011, 32 (28), 6791-6803.

(24) Petkau-Milroy, K.; Brunsveld, L. Supramolecular Chemical Biology; Bioactive Synthetic Self-Assemblies. Org. Biomol. Chem. 2013, 11 (2), 219-232.
(25) Stupp, S. I.; Pralle, M. U.; Tew, G. N.; Li, L.; Sayar, M.; Zubarev, E. R. Self-Assembly of Organic Nano-Objects into Functional Materials. MRS Bull. 2000, 25 (04), 42-48.

(26) Hosseinkhani, H.; Hong, P.-D.; Yu, D.-S. Self-Assembled Proteins and Peptides for Regenerative Medicine. Chem. Rev. 2013, 113 (7), 4837-4861.

(27) Cui, H.; Webber, M. J.; Stupp, S. I. Self-Assembly of Peptide Amphiphiles: From Molecules to Nanostructures to Biomaterials. Biopolymers 2010, 94 (1), 1-18.

(28) Matson, J. B.; Stupp, S. I. Self-Assembling Peptide Scaffolds for Regenerative Medicine. Chem. Commun. 2012, 48 (1), 26-33.

(29) Mumcuoglu, D.; Sardan Ekiz, M.; Gunay, G.; Tekinay, T.; Tekinay, A. B.; Guler, M. O. Cellular Internalization of Therapeutic Oligonucleotides by Peptide Amphiphile Nanofibers and Nanospheres. ACS Appl. Mater. Interfaces 2016, 8 (18), 11280-11287.

(30) Webber, M. J.; Tongers, J.; Renault, M.-A.; Roncalli, J. G.; Losordo, D. W.; Stupp, S. I. Development of Bioactive Peptide Amphiphiles for Therapeutic Cell Delivery. Acta Biomater. 2010, 6 (1), $3-11$.

(31) Liu, M.; Barany, G.; Live, D. Parallel Solid-Phase Synthesis of Mucin-Like Glycopeptides. Carbohydr. Res. 2005, 340 (13), 21112122.

(32) Berges, C.; Naujokat, C.; Tinapp, S.; Wieczorek, H.; Höh, A.; Sadeghi, M.; Opelz, G.; Daniel, V. A Cell Line Model for the Differentiation of Human Dendritic Cells. Biochem. Biophys. Res. Commun. 2005, 333 (3), 896-907.

(33) Wischke, C.; Borchert, H.-H.; Zimmermann, J.; Siebenbrodt, I.; Lorenzen, D. R. Stable Cationic Microparticles for Enhanced Model Antigen Delivery to Dendritic Cells. J. Controlled Release 2006, 114 (3), 359-368.

(34) Shariat, A.; Karimi, M. H.; Mokhtariazad, T.; Moazzeni, S. M.; Geramizadeh, B.; Hosseini, S. A. M.; Yaghobi, R. Maturation State and Function of Monocyte Derived Dendritic Cells in Liver Transplant Recipients. Iran J. Immunol. 2014, 11 (3), 153.

(35) Pagán, A. J.; Pepper, M.; Chu, H. H.; Green, J. M.; Jenkins, M. K. CD28 Promotes CD4+ T Cell Clonal Expansion During Infection Independently of Its Ymnm and Pyap Motifs. J. Immunol. 2012, 189 (6), 2909-2917.

(36) Zhou, L.-J.; Tedder, T. F. A Distinct Pattern of Cytokine Gene Expression by Human CD83+ Blood Dendritic Cells. Blood 1995, 86 (9), 3295-3301.

(37) Zhou, L.-J.; Tedder, T. F. CD14+ Blood Monocytes Can Differentiate into Functionally Mature CD83+ Dendritic Cells. Proc. Natl. Acad. Sci. U. S. A. 1996, 93 (6), 2588-2592.

(38) Engering, A.; Geijtenbeek, T. B.; van Vliet, S. J.; Wijers, M.; van Liempt, E.; Demaurex, N.; Lanzavecchia, A.; Fransen, J.; Figdor, C. G.; Piguet, V. The Dendritic Cell-Specific Adhesion Receptor DC-SIGN Internalizes Antigen for Presentation to T Cells. J. Immunol. 2002, 168 (5), 2118-2126.

(39) Brimble, M. A.; Kowalczyk, R.; Harris, P. W.; Dunbar, P. R.; Muir, V. J. Synthesis of Fluorescein-Labelled O-Mannosylated Peptides as Components for Synthetic Vaccines: Comparison of Two Synthetic Strategies. Org. Biomol. Chem. 2008, 6 (1), 112-121.

(40) Šardzík, R.; Noble, G. T.; Weissenborn, M. J.; Martin, A.; Webb, S. J.; Flitsch, S. L. Preparation of Aminoethyl Glycosides for Glycoconjugation. Beilstein J. Org. Chem. 2010, 6 (1), 699-703.

(41) Motiei, L.; Rahimipour, S.; Thayer, D. A.; Wong, C.-H.; Ghadiri, M. R. Antibacterial Cyclic D, L-A-Glycopeptides. Chem. Commun. 2009, 25, 3693-3695.

(42) Arcangeli, A.; Toma, L.; Contiero, L.; Crociani, O.; Legnani, L.; Lunghi, C.; Nesti, E.; Moneti, G.; Richichi, B.; Nativi, C. Stable GM3 Lactone Mimetic Raises Antibodies Specific for the Antigens Expressed on Melanoma Cells. Bioconjugate Chem. 2010, 21 (8), $1432-1438$. 